\title{
PEMILIHAN DESAIN INSTALASI PENGELOLAAN AIR LIMBAH BATIK YANG EFEKTIF DAN EFISIEN DENGAN MENGGUNAKAN METODE LIFE CYCLE COST (Studi Kasus di Kampung Batik Semarang)
}

\author{
Miranti Marita Sari, Sri Hartini ${ }^{*}$, Sudarno \\ Program StudiTeknikIndustri, FakultasTeknik, UniversitasDiponegoro, Semarang \\ JI.Prof. H. Sudarto, SH Tembalang - Semarang KodePos 50275
}

\begin{abstract}
Abstrak
Kampung Batik Semarang belum memiliki Instalasi Pengelolaan Air Limbah (IPAL) sehingga air limbah hasil produksi batik langsung di buang pada saluran pembuangan air. Limbah air yang berasal dari proses pewarnaan menyebabkan masalah terhadap lingkungan. Hal ini menyebabkan pencemaran pada saluran pembuangan air di lingkungan tersebut sehingga air di dalam saluran pembuangan bewarna hitam pekat. Uji terhadap BOD dan COD pada naftol sebesar $5 \mathrm{mg} / \mathrm{l}$ dan $83,9 \mathrm{mg} / \mathrm{l}$, sedangkan pada garam sebesar $14 \mathrm{mg} / \mathrm{l}$ dan $839 \mathrm{mg} / \mathrm{l}$. Nilai COD tersebut melebihi baku mutu yang telah ditetapkan pemerintah sebesar $100 \mathrm{mg} / \mathrm{l}$. Penelitian ini menggunakan rancangan IPAL proses fisika kimia dan elektrokoagulasi. Rancangan tersebut diharapkan dapat mengurangi COD yang terkandung dalam limbah batik. Penelitian ini adalah IPAL dengan menggunakan IPAL dengan proses fisika kimia mempunyai efisiensi sebesar 19,85\% hingga 72,7\%. Biaya IPAL dengan proses fisika kimia adalah sebesar Rp 5.409.909,00 per tahun dengan menggunakan metode Life Cycle Cost (LCC). Sedangkan IPAL dengan proses elektrokoagulasi mempunyai efisiensi sebesar $89 \%$ dengan biaya yang di butuhkan sebesar Rp 7.887.546,00 per tahun dengan menggunakan metode Life Cycle Cost (LCC). Maka rekomendasi IPAL terpilih untuk Kampung Batik Semarang adalah IPAL dengan proses fisika kimia.
\end{abstract}

Kata Kunci: limbah cair batik, IPAL, fisika kimia, elektrokoagulasi, life cycle cost (LCC)

\begin{abstract}
Kampung Batik Semarang has not had Installing a Wastewater Treatment Plant (WWTP) so that the waste water from batik production directly flows to sewer. Waste water from the dyeing process is cause environmental problems. This leads to contamination of the water in the drain so that the water in the sewer colored black. BOD and COD test against the naphthol at $5 \mathrm{mg} / \mathrm{l}$ and $83.9 \mathrm{mg} / \mathrm{l}$, while the salt of $14 \mathrm{mg} / \mathrm{l}$ and $839 \mathrm{mg} / \mathrm{l}$. The COD value exceeds the quality standards set by the government at $100 \mathrm{mg} / \mathrm{l}$. This study uses the WWTP design electrocoagulation process chemistry and physics. The design isexpected toreduce theCODof wastecontained inbatik. The results of this study that use WWTP with chemical physics processes have an efficiency of 19,85\% to 72,7\%. The cost involved with the process of chemical physics WWTP is Rp 5.409.909,00 per year using Life Cycle Cost ( LCC). While the WWTP with electrocoagulation process has an efficiency of $89 \%$ at cost it need Rp 7.887.546,00 per year using the Life Cycle Cost ( LCC ). So the recommendation WWTP to Kampung Batik Semarang is WWTP with chemical physics process.
\end{abstract}

Keyword: batik waste water, WWTP, chemistry physics process, electrocoagulation process, life cycle cost $(L C C)$

\section{Pendahuluan}

Batik merupakan karya seni adi luhung bangsa Indonesia yang telah turun temurun (Syakur,2008). Pada tanggal 2 Oktober 2009, UNESCO telah menobatkan batik sebagai karya budaya asli

\footnotetext{
${ }^{*}$ Penulis Korespondensi. email: ninikhidayat@yahoo.com
}

J@TI Undip, Vol X, No 1, Januari 2015
Indonesia. Namun, peningkatan respon konsumen terhadap batik tidak dibarengi dengan pemahaman pengrajin batik mengenai dampak limbah terhadap lingkungan.

Limbah produksi batik pada umumnya terdiri dari sisa mori, ceceran lilin, sisa air pewarnaan, sisa lilin dan air pelorodan. Limbah cair proses batik di UKM Jogjakarta sekitar 1251 per kilogram Batik (Yulianto, 2012), sedangkan Pekalongan sekitar 100 
liter per kilogram batik (Wicaksono, 2012). Beberapa penelitian mengenai tingkat sustainabilitas terhadap produk batik dengan metode Life Cycle Assesment menyimpulkan bahwa produk batik dikatakan affordable tapi tidak sustainable, karena nilai Eco Efficiency Index masih kurang dari 1. Echo efficiency batik pekalongan sebesar 68,74\% (Diana et. Al, 2012), Echo efficiency batik Solo sebesar 75,6\% (Dyah et.al, 2013) sedangkan echo efficiency batik bantul sebesar 64,4\% (Yulianto, 2012).

Pencemaran terutama bersumber dari limbah cair yang berupa zat warna yang dihasilkan sisa bahan pewarna, proses pencucian dan pembilasan kain batik. Warna merupakan indicator pencemaran air. Pembuangan air limbah berwarna tidak hanya merusak estetika badan air penerima tapi juga meracuni biota air. Disamping itu, kepekatan warna dapat menghalangi tembusnya sinar matahari sehingga akan menghambat proses fotosisntesis di air. Akibatnya, oksigen yang dibutuhkan untuk kehidupan biota air akan berkurang (Nasution, 2009). Hasil uji laboratorium dari Badan Lingkungan Hidup (BLH) DIY terhadap dua sampel menunjukkan bahwa limbah batik di Kecamatan Lendah sudah melebihi ambang baku mutu. Sedangkan air Sungai Rowo Jembangan yang terkena aliran pembuangan limbah batik masih di bawah ambang baku, namun untuk air sumur sudah tercemar bakteri coliform dan coli tinja. BLH memakai 26 parameter untuk menentukan ambang batas mutu bagi air sungai, air bersih 2 parameter, dan limbah batik 3 paramater. Parameter tersebut sesuai dengan yang telah ditentukan dalam Pergub DIY No 7 Tahun 2010 tentang batas maksimal yang diperbolehkan sesuai standar baku mutu limbah cair kegiatan industry batik (krjogja.com). UKM Batik Semarang yang berlokasi di Bubakan menghasilkan limbah perca sekitar 5 meter, limbah malam 1694 gram, ceceran zat warna sebanyak 20 gram dan limbah air sebanyak 80 liter untuk setiap produksi 30 meter batik (Hartini et.al, 2012). Untuk mengurangi dampak limbah batik terhadap lingkungan, perlu ada pengolahan air limbah batik sebelum di buang pada badan air penerima. Pengolahan air limbah di salah satu UKM Laweyan dengan kimia fisika yang terdiri dari 4 tahap (koagulasi, ekualisasi /sedimentasi, adsorbs arang, dan adsorbs zeolit) diestimasi dapat meningkatkan tingkat sustainabilitas batik dari 75,6\% menjadi 81 \% (Septiana, 2012). Pengolahan limbah batik dengan IPAL di Pekalongan dapat menurunkan kadar BOD sekitar 38\% dan COD sekitar 35\% (Nasution, 2012).

Limbah zat warna yang dihasilkan dari industri tekstil umumnya merupakan senyawa organik nonbiodegradable, yang dapat menyebabkan pencemaran lingkungan terutama lingkungan perairan. Senyawa zat warna di lingkungan perairan sebenarnya dapat mengalami dekomposisi secara alami oleh adanya cahaya matahari, namun reaksi ini berlangsung relatif lambat, karena intensitas cahaya UV yang sampai ke permukaan bumi relatif rendah sehingga akumulasi zat warna ke dasar perairan atau tanah lebih cepat daripada fotodegradasinya. Dae-Hee, dkk (1999) dan Al-kdasi, dkk (2004)

Jika limbah hasil pewarnaan dibuang langsung tanpa diolah terlebih dahulu, maka aliran limbah tersebut akan melalui perairan di sekitar pemukiman. Dengan demikian mutu lingkungan tempat tinggal penduduk menjadi turun. Limbah tersebut dapat menaikkan kadar COD (ChemicalOxygen Demand). Jika hal ini melampaui ambang batas yang diperbolehkan, maka gejala yang paling mudah diketahui adalah matinya organisme perairan (Alkdasi et al, 2004). Oleh karena itu perlu, dilakukan pengolahan limbah industri tekstil yang lebih lanjut agar limbah ini aman bagi lingkungan.

Beberapa penelitian yang pernah dilakukan mengenai penurunan COD seperti pada pembuatan IPAL dengan koagulan tawas dapat menurunkan kadar COD pada proses aerob hingga 76, $59 \%$ dan pada kondisi anaerob hingga 69,43 \%, masing masing pada waktu tinggal sel 6 jam dan 6 hari (Sianita, dkk, 2010). Sumantri, dkk pada tahun 1998 melakukan penelitian mengenai pengolahan limbah cair industri kecil batik dengan bak anaerobik bersekat (anaerobic baffled reactor) yang menghasilkan penurunan COD dan BOD sebesar $68,20 \%$ dan $52,68 \%$.

Dari hasil pengujian air limbah Kampung Batik Semarang diperoleh bahwa COD yang dihasilkan dari proses pewarnaan batik adalah sebesar $839,7 \mathrm{mg} / \mathrm{l}$ (Hasil Laboratorium, 2013) sedangkan baku mutu COD yang ditetapkan pemerintah yaitu sebesar 100 mg/l (Permen LH No.3/2010). Hal ini berarti COD dari hasil produksi batik melebihi ambang batas yang ditetapkan pemerintah. Kampung Batik Semarang ini belum memiliki Instalasi Pengelolaan Air Limbah (IPAL) sehingga air limbah hasil produksi batik langsung di buang pada saluran pembuangan air. Belum adanya IPAL pada kampung batik ini dikarenakan tidak adanya biaya untuk pengadaan serta kurang adanya kesadaran dari masyarakat untuk menjaga lingkungan.

Oleh karena itu, penelitian ini bermaksud untuk memberikan rekomendasi IPAL yang efektif dan efisien untuk Kampung Batik Semarang dengan memberikan alternatif-alternatif pengolahan IPAL dan biaya yang ditimbulkan dengan menggunakan metode Life Cycle Cost (LCC). Dengan adanya IPAL tersebut diharapkan kadar COD dari limbah yang dihasilkan Kampung Batik Semarang dapat diturunkan sehingga sesuai dengan aku mutu yang telah ditetapkan pemerintah. Selain itu, dengan adanya IPAL tersebut UKM-UKM terhindar dari denda yang ditetapkan pemerintah sebesar Rp. 50.000.000,00 dan pidana kurungan paling lama 
6 bulan. Hal ini tertera dalam Peraturan Daerah Nomor 5 Tahun 2012.

\section{Metode Penelitian}

Langkah awal yang dilakukan dalam penelitian ini adalah mengukur BOD dan COD yang terkandung dalam limbah batik hasil produksi. Dari hasil pengujian laboratorium kadar COD yang dihasilkan dari produksi batik melebihi ambang batas yang ditetapkan pemerintah.Berdasarkan hasil wawancara untuk mengatasi kadar COD yang tinggi dari limbah batik sehingga alternatif IPAL yang digunakan dengan menggunakan proses fisika kimia dan elektrokoagulasi. Setelah didapatkan hasil kadar COD dari pengujian laboratorium, dilakukan perhitungan untuk menentukan ukuran bak berdasarkan waktu tinggal dari masing-masing proses. Dari penentuan bak proses juga dihitung efisiensi yang terjadi pada bak proses tersebut dari setiap jenis IPAL yang dibuat. Data-data yang dibutuhkan untuk bak proses yang digunakan dapat dilihat pada tabel 1. Data-data tersebut diperoleh melalui observasi, interview, dan dokumentasi.

Setelah itu dihitung biaya-biaya yang dikeluarkan untuk capital expenditure, operational expenditure dan social cost and benefit dengan menggunakan metode Life Cycle Cost. Metode ini digunakan karena perhitungan biaya dengan menggunakan metode Life Cycle Costing lebih sederhana dengan komposisi biaya yang sama dengan perhitungan biaya dengan metode yang lain. Life Cycle Costing digunakan untuk pemilihan pembangunan suatu proyek dengan beberapa pilihan alternatif. Kelebihan dari metode ini juga memperhatikan social cost and benefit yang merupakan kompensasi biaya sosial yang timbul akibat adanya kerugian akibat sistem atau proses yang terjadi dan keuntungan yang diperoleh dari segi sosial akibat adanya sistem.

Dari perhitungan efisiensi dan biaya yang dihasilkan dari masing-masing alternatif IPAL maka akan dipilih IPAL dengan efisiensi paling tinggi dan biaya paling rendah.

\section{Hasil \\ Efisiensi}

Pada IPAL dengan proses fisika kimia efisiensi yang terjadi dalam bak koagulasi-flokulasi, sedimentasi, filtrasi, dan absorbi yang didapatkan dari penelitian sebelumnya yaitudari bak koagulasiflokulasi sebesar 19,85\% (Sapta- rini, 2009), dari bak sedimentasi tidak terdapat efisiensi karena hanya terjadi proses pengen- dapan saja, efisiensi pada bak filtrasi sebesar 28,98\% (Muljadi, 2009), sedangkan efisiensi pada bak absorbsi adalah sebesar 72,7\% (Gani, 2008). Hasil COD melalui IPAL dengan proses fisika kimia berkurang dari 839,7 $\mathrm{mg} / \mathrm{L}$ menjadi $60,578 \mathrm{mg} / \mathrm{L}$. Pada IPAL dengan proses elektrokogulasi efisiensi yang terjadi sebesar $89 \%$ (Yulianto dkk, 2009), sehinggahasil COD dengan proses ini dapat berkurang dari $839,7 \mathrm{mg} / \mathrm{L}$ menjadi 92,367 mg/L.

\section{Desain Fisika Kimia}

Perencanaan IPAL proses fisika kimia terdiri dari bak koagulasi - flokulasi, bak sedimentasi, bak filtrasi, dan bak absorsi. Pada proses koagulasi yang akan dilakukan pengadukan cepat dan penambahan koagulan, yaitu tawas.

Tabel 1. Kebutuhan Data

\begin{tabular}{|c|c|c|c|c|c|}
\hline Komponen & Metode & Input & Output & $\begin{array}{c}\text { Teknik } \\
\text { Pengumpulan } \\
\text { Data }\end{array}$ & Referensi \\
\hline \multirow{3}{*}{$\begin{array}{l}\text { Penentuan } \\
\text { biaya }\end{array}$} & \multirow{3}{*}{$\begin{array}{l}\text { LCC } \\
\text { (Fuller, } \\
2005)\end{array}$} & $\begin{array}{l}\text { - Ijuk } \\
\text { - Pasir kuarsa } \\
\text { Karbon aktif }\end{array}$ & & $\begin{array}{l}\text { Interview, } \\
\text { observasi, dan } \\
\text { dokumentasi }\end{array}$ & $\begin{array}{l}\text { - http://ijuktambangdanbatukarang.blo } \\
\text { gspot.com } \\
\text { - http://www.purewatercare.com } \\
\text { - http://www.purewatercare.com } \\
\text { - }\end{array}$ \\
\hline & & $\begin{array}{l}\text { IPAL dengan proses } \\
\text { elektrokoagulasi } \\
\text { a. Capital expenditure: } \\
\text { - Bak akuarium } \\
\text { - Power supply } \\
\text { - Pompa } \\
\text { - Ijuk } \\
\text { - Pasir kuarsa } \\
\text { - Karbon aktif }\end{array}$ & $\begin{array}{l}\text { Keseluruhan capital } \\
\text { expenditure dan } \\
\text { operational } \\
\text { expenditure dari } \\
\text { alternatif-alternatif } \\
\text { pengolahan limbah }\end{array}$ & $\begin{array}{c}\text { Interview, } \\
\text { observasi, dan } \\
\text { dokumentasi } \\
\text { Interview, } \\
\text { observasi, dan } \\
\text { dokumentasi }\end{array}$ & $\begin{array}{l}\text { - } \text { http://koihiasnusa.wordpress.com } \\
\text { - } \text { http://www.tequipment.net } \\
\text { - } \text { http://mesinterbaru.blogspot.com } \\
\text { - } \text { http://ijuktambangdanbatukarang.blo } \\
\text { gspot.com } \\
\text { - } \text { http://www.purewatercare.com } \\
\text { - http://www.purewatercare.com }\end{array}$ \\
\hline & & $\begin{array}{l}\text { IPAL dengan proses } \\
\text { elektrokoagulasi } \\
\text { b. Capital expenditure: } \\
\text { - Bak akuarium } \\
\text { - Power supply } \\
\text { - Pompa }\end{array}$ & $\begin{array}{l}\text { Keseluruhan capital } \\
\text { expenditure dan } \\
\text { operational } \\
\text { expenditure dari } \\
\text { alternatif-alternatif } \\
\text { pengolahan limbah }\end{array}$ & $\begin{array}{c}\text { Interview, } \\
\text { observasi, dan } \\
\text { dokumentasi }\end{array}$ & $\begin{array}{ll} & \text { http://koihiasnusa.wordpress.com } \\
\text { - http://www.tequipment.net } \\
\text { - http://mesinterbaru.blogspot.com }\end{array}$ \\
\hline
\end{tabular}


Bagian kedua sampai kelima merupakan proses flokulasi, sekat yang dibuat atas bawah sehingga air akan mengalir melalui sekat-sekat tersebut sehingga terjadi pengadu- kan lambat.

Dari bak koagulasi-flokulasi air limbah akan dipompa ke dalam bak sedimentasi agar flok yang terbentuk dari proses koagulasi-flokulasi akan mengendap. Selanjutnya air limbah dari proses sedimentasi akan mengalir ke bak filtrasi secara gravitasi. Bak filtrasi ini akan berisi zeolit, ijuk, kerikil, dan pasir kuarsa. Tahap terakhir IPAL dengan proses fisika kimia adalah absorbsi. Dalam bak absorbsi ini juga berisi karbon aktif yang berfungsi untuk menyerap COD. Pada tahap ini pengurangan COD paling besar karena karbon aktif dapat menyerap COD dengan baik. Desain IPAL dengan proses fisika kimia dapat dilihat pada Gambar 1.

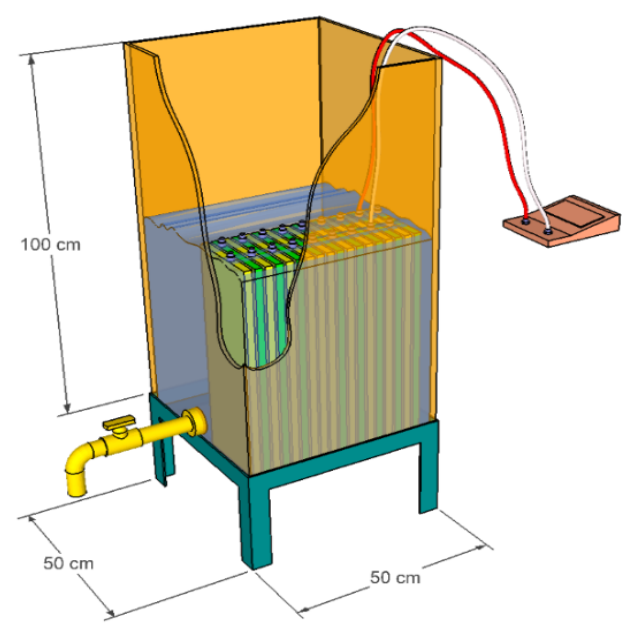

Gambar 2. Desain IPAL dengan Proses Elektrokoagulasi

\section{Elektrokoagulasi}

Penurunan konsentrasi COD dalam elektrokoagulasi ini disebabkan proses oksidasi dan reduksi didalam reaktor elektrokoagulasi tersebut. Pada elektroda-elektroda terbentuk gas oksigen dan hidrogen yang akan mempengaruhi reduksi COD. Desain elektrokoagulasi terdapat pada gambar 2.

\section{Perhitungan Life Cycle Cost}

Hasil dari perhitungan Life Cycle Cost IPAL dengan proses fisika kimia dan elektrokoagulasi terdapat pada tabel 2.

Capital expenditure pada IPAL dengan proses fisika kimia yang dibutuhkan adalah sebesar $\mathrm{Rp}$ 2.556.820,00 per tahun. Biaya tersebut dikeluarkan untuk pembangunan dudukan bak, pembelian bak dan pompa. Pada operational expenditure biaya yang dikeluarkan sebesar Rp 4.690.173,00 per tahun. Biaya-biaya operational expenditure meliputi maintenance pompa, biaya energi, pembelian bahanbahan untuk mengolah air limbah, serta biaya tenaga kerja. Sehingga social cost yang dikeluarkan adalah sebesar Rp 905.874,00 per tahun per UKM.

Pada IPAL dengan proses elektrokoagulasi capital exenditure yang dikeluarkan adalah sebesar $\mathrm{Rp}$ 3.711.967,00. Biaya tersebut digunakan untuk membeli bak proses, power supply, pompa, aluminium, dan besi. Operational expenditure yang dikeluarkan sebesar 4.365.329,00 per tahun. Biayabiaya operational expenditure meliputi maintenance pompa dan power supply, biaya energi, serta biaya tenaga kerja. Sehingga social cost yang dikeluarkan adalah sebesar Rp 1.009.662,00 per tahun per UKM.

\section{Kesimpulan}

Dari hasil penelitian yan telah dilakukan diperoleh bahwa efisiensi yang terjadi pada IPAL dengan proses fisika kimia lebih besar dibandingkan dengan proses elektrokoagulasi. Efisiensi IPAL dengan proses fisika kimia adalah sebesar 19,85\% hingga $72,7 \%$. Sedangkan, efisiensi yang terjadi pada IPAL dengan proses elektrokoagulasi adalah sebesar $89 \%$. Dilihat dari segi biaya, biaya yang timbul dari IPAL dengan proses fisika kimia adalah sebesar Rp 7.246.993,00 per tahun. Sedangkan untuk IPAL dengan proses elektrokoagulasi sebesar Rp 8.077.296,00 per tahun.Sehingga, Rekomendasi IPAL yang digunakan untuk Kampung Batik Semarang adalah IPAL dengan proses fisika kimia.

Tabel 2. Hasil Perhitungan Life Cycle Cost

\begin{tabular}{|c|c|c|c|}
\hline & & Fisika Kimia & Elektrokoagulasi \\
\hline \multirow[t]{3}{*}{ Biaya } & $\begin{array}{c}\text { Capital excpenditure / } \\
\text { per tahun }\end{array}$ & Rp 2.556.820,00 Rp 7.246.993,00 & Rp 3.711.967,00 \\
\hline & Operationalexcpenditure & Rp 4.690.173,00 & Rp 4.365.329,00 \\
\hline & $\begin{array}{c}\text { Social cost / per tahun / } \\
\text { UKM }\end{array}$ & $\operatorname{Rp} 905.874,00$ & $\operatorname{Rp} 1.009 .662,00$ \\
\hline
\end{tabular}




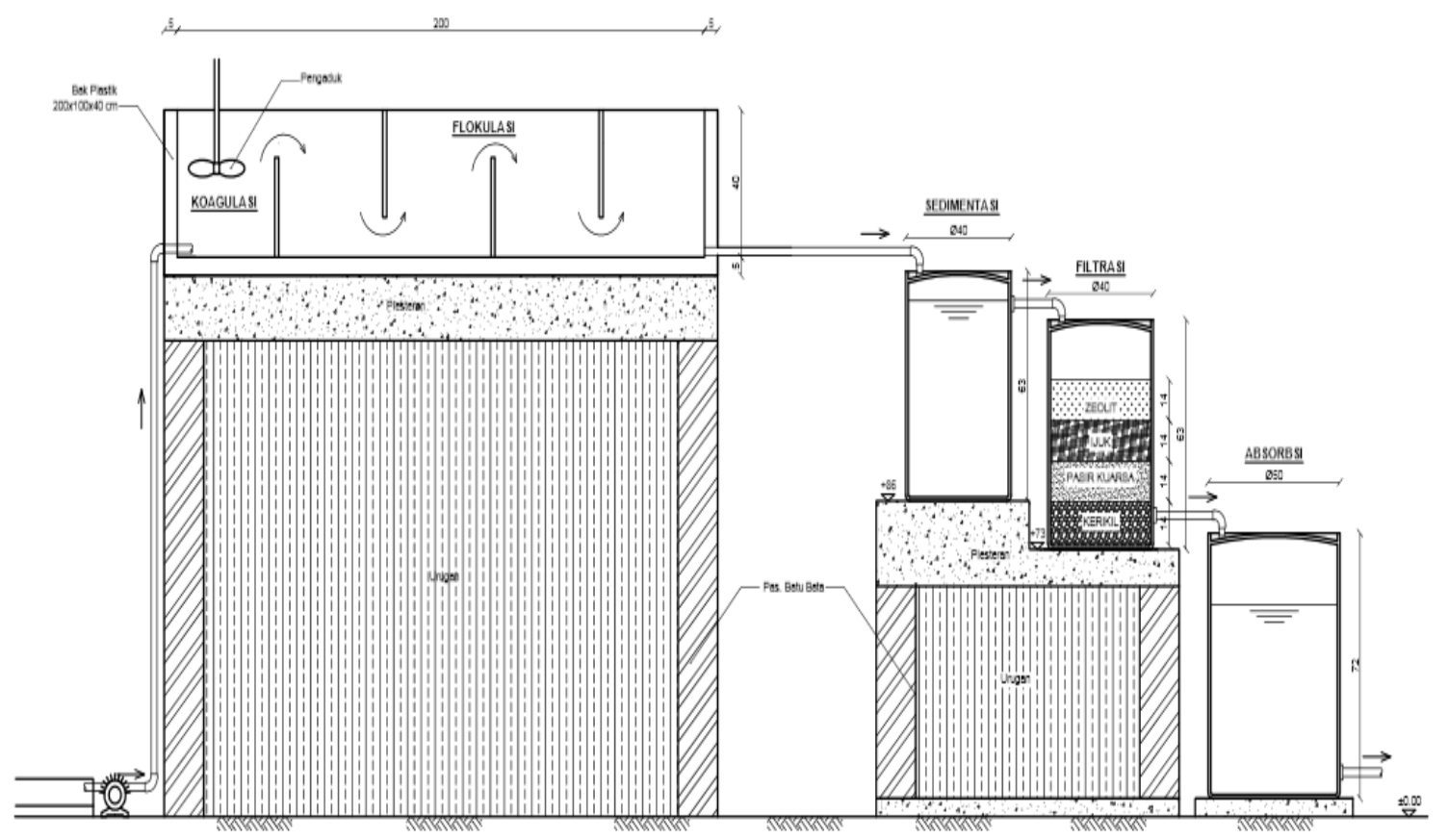

Gambar 1. Desain IPAL dengan Proses Fisika Kimia

\section{Daftar Pustaka}

Al-Kdasi, A., Idris, A., Saed, K. dan Guan, C.T., 2004. Treatment of textile wastewater by advanced oxidation processes. Global Nest the Int. J. 6: 222-230.

Dae-Hee A., Won-Seok C., Tai-Il Y. 1999. Dyestuff wastewater treatment using chemical oxidation, physical adsorption and fixed bed biofilm process, Process Biochemistry 34: 429-439.

Fuller, Sieglinde R., 2005, Life-Cycle Cost Analysis. National Institute of Standards and Technology Gaithersburg.

Gani, M. Ulum A. 2008. Percobaan Penyerapan Limbah Industri Menggunakan Karbon Aktif Dari Batubara Tanjung Tabalong, Kalimantan Selatan. Pusat Penelitian Geoteknologi, Lembaga Ilmu Pengetauan Indonesia. Bandung.

Muljadi. 2009. Efisiensi Instalasi Pengolahan Limbah Cair Industri Batik Cetak dengan Metode Fisika-Kimia dan Biologi Terhadap Penurunan Parameter Pencemar (BOD, COD, dan Logam Berat KROM (Cr). Program Studi Ilmu Lingkungan Pasca Sarjana, Universitas Sebelas Maret. Surakarta.

Saptarini, Dyah. 2009. Pengolahan Limbah Cair Industri Batik Dengan Metode KoagulasiFlokulasi Dan Adsorpsi Sistem Batch. Program Pascasarjana, Universitas Gadjah Mada. Yogyakarta.
Sianita, dkk. 2010. Kajian Pengolahan Limbah Cair Industri Batik, Kombinasi Aerob - Anaerob Dan Penggunaan Koagulan Tawas. Fakultas Teknik, Universitas Diponegoro. Semarang

Yulianto, Andik, dkk. 2009. Pengolahan Limbah Cair Industri Batik Pada Skala Laboratorium Dengan Menggunakan Metode Elektrokoagulasi. Jurusan Teknik lingkungan, Universitas Islam Indonesia. Yogyakarta.

www.purewatercare.com/pwc/index.php?categoryID $=100$ diakses pada tanggal 15 Oktober 2013 pukul 12:07

www.aquariashop.indonetwork.co.id/1575472 diakses pada tanggal 15 Oktober 2013 pukul $12: 12$

www.mesinterbaru.blogspot.com/2013/02/hargamesin-air-murah-terbaru-2013.html diakses pada tanggal 14 Oktober 2013 pukul 19:27

www.cangkirkopi.com/aquashop/itemview/212/batuzeolite.html diakses pada tanggal 15 Oktober 2013 pukul 11:50

www.kimia29.blogspot.com/2010/05/tawasbongkah.html diakses pada tanggal 15 Oktober 2013 pukul 11:51

www.joyorejo-batualam.blogspot.com/2009/09/daftar-harga-batukerikil-ud-joyorejo .html diakses pada tanggal 15 Oktober 2013 pukul 12:03 
www.ijuktambangdanbatukarang.blogspot.com/ diakses pada tanggal 15 Oktober 2013 pukul 11:46

www.purewatercare.com/jual_pasir_silika.php?id=ju al,pasir,silika diakses pada tanggal 15 Oktober 2013 pukul 11:37 www.koihiasnusa.wordpress.com/2011/10/05/hargaaquarium/ diakses pada tanggal 15 Oktober 2013 pukul 12:15

www.gwinstek.com/en/product/productdetail.aspx?pi $\mathrm{d}=38 \& \mathrm{mid}=76 \& \mathrm{id}=177$ diakses pada tanggal 15 Oktober 2013 pukul 12:16 